\title{
The Other Europeans: Immigration into Latin America and the International Labour Market (1870-1930)
}

\author{
Blanca Sánchez-Alonso
}

\begin{abstract}
Not all Europeans migrated to the United States. Between 1879 and 193013 million of Europeans went to Latin America; however, Latin America is not fully incorporated into current debates on the cost and benefits from Atlantic migration. This paper surveys Latin America immigration experience since the late nineteenth century to 1930. It assesses inferences about European migrants in Latin America derived from the experience of migrants in the United States and questions its validity. The topics covered here include migration trends and chronology, national origin of the flows and the evolution of real wages. New data on the cost of passages for transatlantic migration is also presented. This is followed by an examination of the immigrants' contribution to economic growth in Latin America dealing basically with the issue of human capital brought in by European immigrants. The extent to which immigrants alter the composition of the labour force and the demographic structure, both in the short and the long run is also examined. A final section concludes with some new avenues for future research.
\end{abstract}

Keywords: Immigration, Latin America, Demography, Economic Development, International Comparisons

JEL Classification: N01 N36

Blanca Sánchez-Alonso: Universidad San Pablo-Ceu e Insituto Figuerola de Historia Económica. Dpto. de Economía, Julián Romea 23, 28003 Madrid (Spain).

Email: blanca@ceu.es

http://www.uc3m.es/uc3m/inst/LF/subpages/personal/blanca sanchez.html 
THE OTHER EUROPEANS: IMMIGRATION INTO LATIN AMERICA AND

THE INTERNATIONAL LABOUR MARKET (1870-1930)*

\author{
Blanca Sánchez-Alonso \\ Universidad San Pablo-Ceu \\ Dpto. de Economía \\ Julián Romea 23 \\ 28003 Madrid (Spain) \\ blanca@ceu.es
}

\begin{abstract}
Not all Europeans migrated to the United States. Between 1879 and 193013 million of Europeans went to Latin America; however, Latin America is not fully incorporated into current debates on the cost and benefits from Atlantic migration. This paper surveys Latin America immigration experience since the late nineteenth century to 1930. It assesses inferences about European migrants in Latin America derived from the experience of migrants in the United States and questions its validity. The topics covered here include migration trends and chronology, national origin of the flows and the evolution of real wages. New data on the cost of passages for transatlantic migration is also presented. This is followed by an examination of the immigrants' contribution to economic growth in Latin America dealing basically with the issue of human capital brought in by European immigrants. The extent to which immigrants alter the composition of the labour force and the demographic structure, both in the short and the long run is also examined. A final section concludes with some new avenues for future research.
\end{abstract}

* I am grateful to Alejandro Vázquez and Bruce Sacerdote for their data on passage fares. Roberto Cortés Conde and Carlos Marichal made many insightful comments while Patrick K. O'Brien contributed with extremely useful suggestions. All remaining errors are mine. 
The role of Latin America in the international economy has changed in many ways since the late nineteenth century particularly in relation to the international labour market. Around 1900, Latin America was an area of destination for millions of immigrants, mainly Europeans. By the end of the twentieth century, Latin America had experienced a "population explosion" and the region is no longer an area of immigration. On the contrary, one of the main features of almost all Latin American countries nowadays is the high volume of emigration to the United States and Europe.

This paper concentrates on the so called "age of mass migration", 1870-1930, and will attempt to bring Latin America histories of migration in the Atlantic economy, a history still biased clearly in favour of the United States Immigration history has been guilty of an "American bias" even though since the 1960s historians like Frank Thistlethwaite (1960) and John D. Gould $(1979,1980)$ praised for a comparative approach in immigration research. The revival of migration studies in the 1990s showed and effort to integrate countries other than the US, Argentina being the case in point, (Hatton and Williamson 1998) but the core of the analysis is still the American experience.

Text books on economic growth in the long run or economic history in Latin America concentrate on trade and capital and devote only a few pages to the relationship of Latin American countries with the international labour markets. Particularly British historians such as Platt or Ferns focused their research on trade and capital since those were the basic links of the British economy with Latin America during the modern period. Since the British were not a major immigrant groups in Latin America, they hardly considered the role of foreign labour. For the colonial period the preferential attention of social scientist is given to native populations and coerced migration from Africa, and to a much lesser degree to free immigration. African slaves were part of the world supply of labour force to Latin America. In terms of immigration alone, America was an extension of Africa rather than Europe until late in the nineteenth century.

Research on immigration in Latin America since the Industrial Revolution is a comparatively neglected field constrained by a narrow conception of the "Atlantic Economy" and some over-simplifications of the Latin experience during the age of mass migration. The experiences of Latin American countries are not fully incorporated into current debates on the cost and benefits from Atlantic migration despite the fact that 13 million of Europeans migrated to that region between 1870 and 1930 (a higher number 
than to Australia and Canada). Even the most favoured country by researchers, Argentina, still lags behind research done for the United States, Australia and Canada.

This paper draws together, in the form of an analytical survey, a number of different aspects of the Latin America immigration experience since the late nineteenth century to 1930. Its main objective is to rethink the role of European migration to Latin America and to clarify some over-simplifications of the Latin experience during the age of mass migration.

Section I discusses to what extent Latin America mimics the experience of the USA focusing on migration trends, national origins of immigrants, the evolution of real wages and the costs of passage across the Atlantic. Did migrants contribute to growth is the question addressed in section II by analysing how much human capital was brought in by immigrants and how did they adjust to the labour market. Then, the extent to which immigrants alter the composition of the labour force and the demographic structure, both in the short and the long run is examined in section III. As a conclusion, the paper includes some new avenues for future research.

\section{Section I. The international labour market: why immigration into Latin}

\section{America lagged behind the United States?}

Improvements in transport and communication over the nineteenth century and the progressive elimination of institutional barriers to commerce induced an impressive increase in commodity and factor mobility. About 60 million Europeans migrated to economies of the New World characterized by scarcities of capital and labour and by cheap and abundant land. Not all countries in Latin America suffered from labour scarcity. Mexico had a relatively large native population and Brazil had both a large slave and free labour force. Resource abundance with labour scarcity certainly characterized the River Plate area and the Brazilian hinterland. Nevertheless, almost all Latin American governments tried to attract foreign labour to prevent labour shortages in specific sectors of the national economies and some governments thought that immigration of culturally "superior" Europeans could contribute to economic and social modernization.

Ferenczi and Willcox, $(1929,1931)$ document the main trends in international migration and show that the majority of European immigrants went to the United States. 
Until the last quarter of the nineteenth century Latin America remained marginal to international market in free labour ${ }^{1}$. Political instability in several new Republics; the low demand for free labour in the majority of Latin American countries who possessed either large native populations (Mexico) or used slaves (Brazil and Cuba); the high cost of the passage; unfavourable geographies and climates in the hinterland; unattractive political and cultural characteristics; all help to explain why Latin America lagged well behind the United States as a destination for immigrants.

After 1870 the situation changed. Political stability and the emergence of policies design to attract foreign immigrants that had been growing since the 1850s and 1860s including religious freedom, rights of private ownership and respect for civil rights, friendlier attitudes towards foreigners, all helped. The story is well known: exports rose, capital flows from Europe came on stream and investment in railways altered prospects for the exploitation of the regions abundant in natural resources (Bethell 1986, Bulmer-Thomas 1994).

Argentina, Brazil after the abolition of slavery, Uruguay and Cuba were the main destination for foreign labour. More than 90 percent of the 13 million European immigrants who travelled to Latin America between 1870 and 1930 chose these four countries although modest immigration flows to countries such as Chile, Venezuela or Mexico occurred. Others like Paraguay or Peru failed almost completely to attract European immigrants.

Gross figures differ considerably from net immigration supposedly because one of the main features of European immigration to Latin America was an exceptional rate of return migration (Gould 1980). Sánchez-Albornoz (1986) estimates that between 1892 and 1930 only 46 percent of immigrants remained permanently in the state of Sao Paulo and the same rate is found in Cuba (47 percent) between 1902 and 1930. For Argentina it has been calculated that the rate of return was around 53 percent (Rechini de Lattes and Lattes 1975). But return migration increased all over the world from the 1880s onwards. For example an increasing fraction of those who migrated to the United States after 1890 never intended to remain permanently and returned to their home country. Temporary movements in search of higher wages often over long distances and across frontiers, was an established tradition in many of the regions from which the "new" immigrants were drawn.

Net immigration in Argentina over the period 1881-1930 reached 3.8 million. Uruguay attracted nearly 600,000 immigrants during the same period. More or less the 
same number remained in Cuba between 1902 and 1930. Whereas 200,000 people went to Chile only 25,000 immigrants entered Paraguay and Mexico received less than 18,000 net immigrants between 1911 and 1924 (Ferenczi and Willcox 1929). The ability of Argentina to attract large numbers of immigrants relative to its own population is striking not only in the American context but compares favourably with Australia and Canada. In 1910-14 foreigners represented 14.5\% of total population in the United States but around 30\% of the total population in Argentina. Prima facie, immigrants could have been more significant for the development of Argentina than the United States particularly regarding the impact of immigrants upon the receiving country.

European sources of emigration changed over time. In the central decades of the nineteenth century dominant migratory streams came from the British Isles, Germany and the Scandinavian countries. Southern and Eastern Europeans followed in the 1880s (Gould 1979). An "emigration life cycle" related to demographic transition, industrialization and the "pulls" of a growing stock of previous migrants abroad developed has been well documented (Hatton and Williamson 1998, chap.3). Southern and Eastern European countries entered into the upswing of their emigration cycle in decades prior to World War One.

The question of timing is crucial in the new perspective of analysis and comparisons presented here. Latin America was a latecomer to the age of mass migration. Yet, immigrants did not arrive in a vacuum and the experience of pioneers and early networks conditioned the assimilation and performance of the followers. When mass European immigration into Latin America started to flow in the 1880s, it was clear that the region could not compete with the United States. Hardly any country of immigration could compete with the extraordinary attraction of the United States. Over the nineteenth century the United States absolutely dominated the European flow.

Europeans from these so called "new emigration countries" had a wider array of options open to them than those who crossed the Atlantic in the middle of the nineteenth century. They could, and many did, opt for the United States, Canada and Australia but Latin American countries made efforts around these decades to attract European immigrants as voyages by sea became shorter, safer and cheaper. The significance of the transport revolution can not be neglected for some countries in Latin America. The average time taken to travel from Northern Spain to Cuba in the 1850s was 38 days by sailing vessels; that had decreased to around 19 days in the 1880s and the steamers 
could do the trip in about 9 to 12 days. On the River Plate route steamers cut the trip from around 55 days in the mid nineteenth century to 12 days in the 1910s (Moya 1998 and Vázquez, 1999). This dramatic reduction in the duration of the Atlantic crossing effectively reduced the cost of migration when the opportunity cost of the earning time wasted on board ship is added to the monetary cost of the trip which was particularly important for the temporary migrants and contributed decisively to increase the number of workers travelling to and from the Americas in search of higher wages.

Unfortunately, long-term annual series for transatlantic passage fares are not available for many European countries, particularly for Southern Europe.

Table 1 presents some useful data on fares for Spanish emigrants to their three main destinations and includes (for comparison) fares paid by British emigrant en route to the United States (Vázquez 1999; Sacerdotre 1995)². A falling trend for fares to Brazil, Argentina and Cuba is observed from the 1850s onwards. The cheapest fares from Spain were for voyages to Cuba but remained quite stable over time ${ }^{3}$. More expensive fares to Brazil and Argentina in the 1870s and 1880s experienced sharp declines in the years of massive emigration. According to Cortés Conde, in the 1880's an Italian worker could finance his transatlantic trip with only 20 percent of his income but Spanish emigrants had to pay for the cost of a passage from incomes of a lower level. For an agricultural worker from the north of Spain the cost of the trip in the 1880s (expressed in the number of working days required to pay the fare) was around 153 working days from a working year of, at most, 250 days but remittances and pre-paid tickets sent home by previous generations of migrants helped to finance the moves of relatives and friends (Cortes Conde 1979; Sánchez-Alonso 2000a). The same situation pertained in Italy and Portugal which explains the massive emigration over the first decade of the twentieth century. Table 2 also documents a convergence between Spanish and British fares: in the first decade of the twentieth century, a period of massive emigration from Spain, when fares to Latin America moved to levels quite similar to those from Britain to the United States. Fares from Spanish ports to the United States in the years 1911-1914 cost $\$ 40$ compared to $\$ 38$ to Brazil, $\$ 33$ to Argentina and \$39 to Cuba (Vázquez 1999). British emigrants paid \$34 to travel to the United States in the same years. Regression analysis suggests that the roles of migratory networks, the diffusion of information (or the lack of it for the United States), culture, language and the existence of long standing colonial links in the case of Cuba explains 
to a larger extent the Spaniards' preference for Latin American countries than the cost of the travel (Sánchez-Alonso 2000b).

Table 1

Transatlantic Passage Fares, 1850-1914 (in current \$)

\begin{tabular}{|l|c|c|c|c|}
\hline & Spain-Brazil & Spain-Argentina & Spain-Cuba & Britain-USA \\
\hline $1850-1860$ & n.a & 45.18 & 33.32 & $44^{\mathrm{a}}$ \\
\hline & & & & \\
\hline $1870-1880^{*}$ & 50.71 & 52.30 & 36.70 & 26.55 \\
\hline $1881-1890 * *$ & 45.54 & 46.60 & 32.10 & 20.40 \\
\hline & & & & \\
\hline $1904-1914 * * *$ & 31.20 & 35.19 & 34.21 & 33 \\
\hline
\end{tabular}

Sources and notes: Spanish data refer to passages from Galician ports. Vázquez González, (1999). Britain-USA data refer to passages from Liverpool to New York. Sacerdote (1995)

* For Latin American countries, 1872-1880

** For Spain-Cuba, 1881-1886

*** For Spain-Brazil, 1906-1914; for Britain-USA, 1904-1912

${ }^{a}$ Fares were exceptionally high for the years 1850-1851. Average fare for 1852-1862 were \$ 36.9

Latin America derived most of its immigrants mainly from Southern Europe, although there was also a considerable flow from Central as well as from East and Southeast European countries in the years prior to the Great War ${ }^{4}$. All of these European regions of departure were countries of emigration to the United States.

The new and massive waves of immigrants from Southern and Eastern Europe, who joined the movement since the 1880s were different from those who crossed the Atlantic in the earlier cycles. The traditional representation in the history of the European migration is that of migrants travelling with families in the mid-nineteenth century (particularly to the United States) while workers from the "new emigration" countries were travelling alone. Three-quarters of the English and welsh, two thirds of the Dutch and two-thirds of the Germans who migrated to the United States in the 1830s were in family groups and a third of them were children under 15 (Erickson 1994). In contrast, since migrants to Latin America were drawn from these "new emigration" countries in Europe, they were supposed to travel alone in high numbers. A large number of immigrants did so but many came in family units with dependants children. Cuban demands for labour pulled in more male immigrants travelling alone than Brazil which attracted relatively more families with children than other countries. Family groups' migrating also to Argentina was surprisingly high. In 1895, 48 percent of 
migrants to Argentina arrived as families, a share that fell to 41 percent of total immigration in 1913. Some of these families (especially among the Italians) were dominated by persons of working age (for example a father and three or four sons) and some nationalities display stronger tendencies to migrate as families. For example, since 1900 around 40 percent of Spanish immigrants to Argentina came as families. Among the Italians family groups were more significant in the nineteenth century and less so in the years before the War. Spanish families tended moreover to be larger than the Italian families (3.2 members per Spanish family in 1913 compared to 2.8 of the Italians and 3 for total immigration (Sánchez-Alonso 1992). Only 18 percent of Spanish immigrants to Sao Paulo arrived without family in 1908-1936 compared to 53 percent of Portuguese arrivals over the same period (Klein 1996). The number of migrant children (32 percent of the flow) was also higher among Spanish families in Brazil than other nationalities (Portuguese migrant children were 19 percent). Parts of the explanation for these variations in migratory strategies arise because information about different labour markets improved over time. Spanish families opted for Brazil and Argentina while individual migrants preferred Cuba where demand for young males was stronger.

The traditional view also stress that high proportions of the "new immigrants" were illiterates and as common labourers entered into unskilled urban occupations rather than agriculture (see section II). They returned home in high numbers both from all the American destinations. Thus there are no clear differences between late nineteenth century European emigrants going to the US than those who opted for Latin American countries. What is different in Latin America is the absence of those migratory flows from Northern Europe that took place before 1880s.

Why Europeans went to Latin America? Economists have assumed that wage differentials between home and destination countries explain migration. Research done by Williamson (1999) allows us to document levels and movements in annual real wages for a large number of countries in the world from 1870 onwards. His data suggests that during the years of massive emigration from Europe Latin American countries could not compete for labour by offering wages at levels offered in the United States. Within Latin America hardly any country could compete with the River Plate. Argentina and Uruguay display the highest wage levels up to 1914 and migrants flowed in higher numbers into Argentina than into Brazil, Cuba or Uruguay. Wages in Argentina and Uruguay were systematically more than 200 percent higher compared to a weighted average of wages of Italy, Portugal and Spain (Table 2 and Figure 1). They 
were over 160 higher in Cuba in the years prior to the Great War, and were also much higher in Mexico. Mexico never experienced mass immigration from Europe.

Brazil, however, represents a puzzle for the traditional explanation of migration based solely on real wage gaps: wages in Brazil were only 50 percent higher than average wage levels in the Mediterranean countries. Furthermore, Brazil had to compete for labour with Argentina and Cuba. Subsidies and contract labour in the coffee sector allowed Brazil to compete for foreign workers. Subsidized immigration allowed potential emigrants to Brazil to overcome the problems involved in funding long distance migration. Research has shown that Spanish emigration was constrained by low levels of income (2000b). In 1911 more than 70 per cent of Spanish immigrants to Sao Paulo arrived with a subsidized passage compared to a mere 24 per cent of Portuguese who had stronger links with Brazil (Klein 1996). Furthermore real advantages of the colono contract also explain the attraction of Brazil. Coffee workers paid no rent, either in money, products or labour in return for some non-monetary provisions, generalizations about the colono's real wages are difficult to make. Food and rent are always an important part of a worker's budget and Holloway (1980) estimates that perhaps 70 percent of a colono family's total income came in the form of free housing, food crops or pasture lands. The system included the security of a minimum annual income, low expenses and consequently the possibility of accumulating savings through free housing and cheap food and finally the possibility of maximizing family income by fully using the labour of all members of the family. Thus, the wage gap is quite irrelevant as an indicator of Brazilian attraction of immigrant families.

Table 2

Real Wage Performance by Decade relative to the Mediterranean Countries (Weighted average of Italy, Portugal and Spain)

\begin{tabular}{|l|r|r|r|r|r|r|r|}
\hline & Argentina & Brazil SE & Brazil NE & Colombia & Cuba & Mexico & Uruguay \\
1850s & & & & & & & \\
1 1870s & 207.7 & 48.9 & 15.5 & 53.1 & & & \\
1890 s & 267.8 & 47.5 & 10.1 & 79.1 & & 173.2 & 324.8 \\
$1909-1913$ & 212.1 & 47.8 & 16.8 & 53.1 & 160.5 & 140.9 & 211.5 \\
1930 s & 201.1 & & & 94.4 & 152.2 & 63 & 187 \\
\hline
\end{tabular}

Sources: Williamson (1999) 
The Brazilian system of subsidizing immigration from Europe is also at odds with the existence of a large native population. The native Brazilian population might well have benefited from a reduction in the supply of unskilled labour from overseas but apparently coffee planters located in the South East of this vast country preferred to subsidize immigration from overseas instead of hiring native workers from low wage areas of Northeast Brazil. Perhaps it was cheaper to pay for transport subsidies for Europeans to cross the Atlantic? Yet it seems unlikely that transportation cost of bringing workers from the Northeast to the Southeast of the country exceeded the cost of transporting workers from Southern Europe to Brazil. Planters had after all done that for two decades after 1850 when slaves where shipped from the less remunerative sugar zones of north eastern regions to Santos and Rio de Janeiro. According to Klein (1999) high transport costs, increasingly severe export taxes and other provincial government restrictions seem to have curtailed seriously this internal slave trade by the late $1870 \mathrm{~s}$ and early 1880s. It might be the case that this experience led planters to reject the idea of bringing native workers from the Northeast to meet expanding demands for agricultural workers in the coffee regions.

Native workers from the North were certainly not immobile. Between 1872 and 1910 hundreds of thousands of workers from the Northeast migrated to the Amazon region (Holloway 1980). From 1914 through 1929 a quarter of a million native internal migrants passed through the labour system regulated by the Sao Paulo government and many others entered the region without official assistance. For some reason, planters preferred European immigrants to the peasant mulatto families from Northeast Brazil. Leff (1982) suggested racial prejudices against native mulattos, but that seems difficult to test and there is no evidence that planters in Brazil wished to develop their country on the basis of white European immigrants (to keep pace with Argentina). On the contrary, a large group of planters tried, unsuccessfully, to develop a mass immigration recruitment program from China on the eve of slavery abolition (Conrad 1975). The Brazilian government finally turned to Japan for a source of Asian workers in the early decades of the twentieth century.

The huge wage gap between sending regions in Southern Europe and Latin American economies has led scholars to argue that the latter enjoyed the advantages associated by Arthur Lewis (1978) and others with an unlimited supply of labour. Cortés Conde (1979) and Diaz Alejandro (1970) also argued that without European immigration the supply of labour to the Argentinean labour market would have became 
highly inelastic and constricting for growth. Leff (1982) observed that the coffee planters in Sao Paulo benefited from two streams of cheap labour: first from slaves and thereafter from an inflow of subsidized immigrants. Immigrant workers from Europe enabled Brazilian planters to maintain wages at low levels. Output and employment in the export sector of the economy expanded over the long cycle 1880-1914 at constant real wages in the coffee plantations.

The Lewis hypothesis concerning the elastic supply of labour from the Mediterranean countries has been put to the test recently. Hatton and Williamson (1994) econometric tests show that while wage gaps between Southern Europe and Latin certainly influenced emigration, the elasticities are relatively small. In all three cases (Italy, Spain and Portugal) a 10 per cent increase in the wage ratio raised emigration by less than one per thousand in the long run compared with Britain and Ireland where long run responses of 2.2 and 2.3 per thousand are observed. Their results lend little support to the prevalent view in the literature that the supply of labour from Southern Europe was highly elastic. The wage gaps may have been large but the elasticities of response seem to have been seriously constrained by high migration costs for low wage workers in Southern Europe. However, more detailed research has shown that emigration was indeed income constrained in Spain and Italy (Sánchez-Alonso 2000b and Faini and Venturini 1994). The unlimited supply of labour hypothesis still waits for a careful research particularly for Brazil which is the more challenging case to test.

Immigrants to Latin America came from latecomer countries to emigration from Europe and were in several respects different from those who crossed the Atlantic in the early phases of the movement. They were not, however, different from those Europeans who opted for the United States in the same period. On balance, the consensus is that Latin America received poorer and potentially less productive immigrants than the United States simply because the dominant stream emigrating from Europe over the years 1880-1914 came from the economically backward areas of Southern and Eastern Europe. However, these "new migrants" arrived also to the United States in huge numbers. What is missing in the Latin American case is the Northern European flows but is it a question of national origins or of different timing of arrival and to different receiving societies? If national origins were roughly the same for immigrants going to North and South America since the late nineteenth century, why then immigrants to Latin America are often represented as poor and backwards? 


\section{Section II. Did immigration contribute to economic growth in Latin} America?

Among scholars the consensus of opinion reached in the United States was that the mass immigration of Europeans had, on the whole, profound positive effects on the rate of growth of the American economy and on the welfare of resident workers (Carter and Sutch 1997). Why such a consensus does not exist in the case of Latin America? Is it because of the lower number of European immigrants in the region or because it is assumed that the overall impact was not so positive? Or is it because we are transferring economic realities of the second half of the twentieth century to the past?

Comparisons with the United States raise the issue of comparable units. There is a long intellectual and scholarly tradition on the exceptionalism of the United States since colonial times until nowadays. Exceptional does not mean different. Exceptionalism projects onto a nation qualities that are envied because they represent deliverance from a common lot. But the concept was created in Europe after American Independence and then it was taken over by the American people. From the beginning the concept had simultaneously clear contradictions and indisputable historical realities. Among the formers the most obvious concerns the existence of slavery till the $1860 \mathrm{~s}$. In the early images of America in early nineteenth century Europe, "there is no hint of the daily, perfunctory brutality of a slave institution" (Appleby 1992). By the end of the colonial period about one out of every five Americans was black and most of them were slaves. Only half of the colonist had English roots and there were sizeable minorities from Germany, Ireland and Scotland (Wells 1992). Members of the Dillingham Commission writing in 1907 and praising "Old Immigrants" in comparisons with "New Immigrants" from Southern and Eastern Europe never mentioned that Benjamin Franklin deplored the arrival of Germans in Pennsylvania because they were "generally the most stupid of their own nation" (Quoted in Schlesinger 1921).

The exceptionalism of the United States for the history of immigration merits discussion particularly drawing the limits of comparisons with Latin American countries. The United States is different since the colonial era particularly regarding the obvious fact that Spanish America had a large native population. Since the Native Americans have never been a potent factor in the nation's history, the whole history of population in the United States is, at bottom, the story of the successive waves of immigration (basically from Europe) and of the adaptation of the new comers. Nothing 
of the sort happened in Latin America even in those countries that during the age of mass migration were preferred destination for European workers. Native population and African slaves were a basic element in the history of Latin America. The contrast between a densely populated Europe and the empty lands in America (a powerful image for potential emigrants) was not possible between Europe and the majority of countries in Latin America.

Exceptionalism is also a concept that applies to the extraordinary economic growth of the US after Independence. The United States doubled Latin America's product per head in 1820 and trebled it in 1870. Income gap grew still more since the late nineteenth century (Prados de la Escosura 2004). In addition, focusing on the contrast with North America inevitably leads to a negative assessment of Latin America's economic behaviour. Per capita income divergence between rich (core) and poor (periphery) countries is the dominant feature of the international economy in the nineteenth century. All countries lagged behind the United States during the period 1850-1930.

Immigration countries in Latin America differ from the United States experience in the comparatively limited number of ethnic groups from whom the emigrants were drawn. Such a concentration of culturally homogeneous immigrant groups present and interesting contrast with the situation in the United States. Immigrants in Latin America (mainly from Southern Europe) are usually represented as poor, backward and illiterate ${ }^{5}$. This "representation" derives from comparisons of the economic backwardness of Italy, Spain and Portugal (measured in terms of per capita incomes) relative to Great Britain and other advanced countries in Europe. But were Italian immigrants themselves poorer than Swedish or Irish immigrants? Were Northern Italians, migrating to Argentina in the 1880s, more backward than the Irish migrants travelling to USA in the 1860s? Their relative economic qualities will be explored by analysing their occupation and literacy rates and their potential contribution to economic development in Latin America.

As usual, these immigrants to Latin America were typically young adults who carried very high labour participation rates to the receiving countries. For them (singles, unskilled, young adults) the potential benefits from migrate would be greater than they would be for the population at large, particularly if they embodied lower levels of country-specific human capital (Hatton and Williamson 1998). How much did it matter 
to have specific human capital in Latin America? If the labour demand was basically of unskilled labour, why being unskilled was a negative feature of the immigrants' supply?

Immigration statistics in receiving countries record the occupation of immigrants in broad generic terms but immigrants often declared an occupation that they believed might be welcomed by a host country. For example, in Cuba the strong pull from the sugar sector explains why 80 to 90 percent of immigrants in the first decade of the twentieth century declared themselves to be hired hands or agricultural workers (Losada 1999).

The broad picture which emerges from aggregate statistics is one of a flow composed overwhelmingly of unskilled rural labour. Even in Argentina, the most diversified of the host economies, the majority of arrivals were agricultural workers and day labourers (jornaleros). Furthermore, the low economic quality of immigrants has been a common feature of almost all accounts of Brazilian immigration. Immigrants arrived in Sao Paulo with the help from subsidized passages and it is assumed that people who went to Brazil were from the lowest economic status of the groups migrating to the New World. It has even been argued that subsidized travel aimed to attract workers so destitute that they could have no choice but to work on the plantations. Thus, Brazil obtained "the poorest of the poor" (Merrick and Graham 1979). However, the fact that emigrants to Brazil from either Portugal, Spain or Italy came from the relatively less backward areas of the north of those countries and not from the poorer south where masses of agricultural day labourers were allegedly living in miserable conditions casts doubts on the expression "the poorest of the poor". It could also be argued that subsidies were a response to the wealth constraint on long distance migration for large segments of the population in Southern Europe. This is the argument applied to the indentured servants' contracts to British colonial America or to the convict workers transported to Australia in the early nineteenth century (Grubb 2003 and Nicholas 1988). However, these coerced migrants are not represented in the literature as ignorant and backward. In the nineteenth century Australia had an assisted migration program, more or less generous according to economic conditions at home: 50 percent of arrivals in the 1870 s were assisted but only 10 percent in the crisis years of the 1890s. Governments in remote countries had little choice but to subsidize the cost of the passage if they wanted to attract immigrants but that does not imply that assisted migrants were, by definition, illiterate and backward. 
Furthermore, in analyzing the characteristics of migrants distinctions between sectors such as agriculture, commerce or industry may be analytically rather meaningless and for two main reasons. First, in their countries of origin the majority of Europeans active populations were employed in agriculture. In 1911, 60 percent of the male labour force in Italy was still engaged in the primary sector and the majority of unskilled labour, no matter what their designation in the statistics, in fact lived in rural areas. Higher percentages of employment in agriculture and lower rates of urbanization are found in Spain, Portugal and other countries of origin of immigrants to Latin America. It would have been surprising that European emigrants to Latin America from Southern and Eastern Europe included lower percentages of agricultural workers than the populations of their countries of origin. Second, since immigrants often change country and occupation at the same time, especially when they are young, it is not clear whether the occupational information of immigrants on arrival is a useful indicator of their subsequent contribution to economic growth. Thus, there are two separable questions: (i) what did an immigrant bring from home? and (ii) what did he/she acquire in the Americas? In spite of that, Hatton and Williamson (2005) stress that the increasing importance of less industrial Eastern and Southern Europe as an emigrant source served to raise the immigrant proportions rural and to lower their average skills and literacy. Is the later an accurate picture of immigrants to Latin America?

Censuses provide with some picture of the adjustment of immigrants to host labour markets. Not all Latin American censuses register population by nationality or country of origin and usually it is impossible to obtain information either on second generation immigrants, to distinguish permanent from temporary immigrants and on their length of stay in the country. Length of stay provides crucial information for any analysis of social mobility. For example, Spanish families resident in the city of Buenos Aires in 1895 worked in low wage occupations but they had been there less than 5 years and a majority had arrived in the late 1880's when the Argentinean government paid for the travel expenses (Sánchez-Alonso 1992). Given time immigrants acquired skills and took advantage of local labour markets ${ }^{6}$.

Population censuses suggest that immigration to Latin America contributed decisively to the urban labour force formation in commerce, industry, building, domestic service and general unskilled labour force. In some countries, some immigrants were successful in becoming owners of industries or commercial enterprises. Even if the goal of many immigrants had been to work on the land, post hoc 
and for a majority migration turned out to be a large range transatlantic move from rural to urban occupations. The highest concentration of immigrants in urban population was found in the River Plate countries. Immigration contributed significantly to urbanization in Latin America (Bourdé 1974, Scobie 1986). In 1910 countries attracting immigrants also had the highest percentages of their population living in towns with 20,000 or more inhabitants: Argentina 28 percent, Uruguay 30 and Cuba 28 percent, compared to the 10 percent ratio for Mexico. Exceptions to this trend included Brazil with a low rate of urbanization (12 percent) and Chile with a high urbanization rate (23 percent) although immigration was lower than in Brazil. In Southern cone countries rates of urbanization were actually higher than rates for the countries of immigrants and similar to the United States (31 percent) (Flora 1973: Mitchell 1993) ${ }^{7}$

Some historians explain the concentration of immigrants in urban activities in Latin America as the outcome of land settlement policies controlled and restricted by a native wealthy oligarchy in sharp contrast with what happened in the United States (Engerman and Sokoloff 2005; Solberg 1987, among others). This stereotype can be rejected and clarified for some countries. For example, Argentina had an open market in land and many more immigrants than is generally believed became farmers (Miguez 1993, Taylor 1997, Adelman 1994). On the Pampas immigrants (particularly Italians) opted to remain as tenants or share-croppers - a rational choice given their lack of capital and knowledge of a new environment and cultivation system (Gallo (1983). Both the time of arrival and the existence of colonial links help to account for differential access to the land. Italians were the most successful in acquiring land in Argentina because they were the pioneer group in the era of mass migration. In the 1880s the proportion of Italian arrivals compared to Spaniards were 14 to 1 . When massive Spanish immigration to the country reached its peak in the years prior to the Great War Argentina was already more urban than the country had been in the 1880s and there were more opportunities to maximize the wage differentials working in the cities than in agriculture (or seasonally in the two sectors).

The colonial links of Portuguese settlers with Brazil and Spaniards with Cuba till 1898, explain why immigrants concentrated in the urban and commercial cities like Rio de Janeiro or Havana and not in the rural sector ${ }^{8}$. Linguistic advantages and established connections with local commercial networks reinforced such trends. Although Spanish immigrants in Mexico barely reached 0.2 percent of Mexican population in 1910, their influence in the creation of Mexican industries, business and commercial enterprises has 
led Mexican historians to define this minority as "privileged immigrants (Lida 1994). During the Porfiriato Spaniards belonged to the upper middle class in the main cities of the country. By 1930 only 3 percent of the Spaniards living in Mexico were engaged in agriculture but were decidedly influential in the Mexican business sector.

Southern European immigrants to Latin American countries were generally over-represented in commercial activities in urban centres. Given high rates of return migration and considering that a high proportion of migrants never intended to settle permanently in the receiving country, what low representation among landowners might imply? Research shows that the main goal of emigrants from Southern Europe was indeed to buy land but in countries of origin (Cinel 1991, Costa Leite 1993).

The representation of immigrants to Latin America as "low quality" labour comes from comparisons carried out within the United States labour market that contrast "old" immigrants coming from Northern Europe and "new" immigrants from Southern and Eastern European countries. But that representation does not pertain to comparisons between Italians in Argentina and in the United States. Italian integration and mobility in the two societies differed markedly. The United States received a larger group of unskilled and illiterate day labourers from the South of Italy while Argentina received the more qualified and literate immigrants from the North. Italians who chose Buenos Aires as their destination generally achieved greater economic and social success than those who went to New York (Baily 1999; Klein 1983).

Literacy has been frequently used as an indicator of the low quality of the immigrants in Latin America (Cipolla 1969). Since literacy rates were lower in sending countries than for Northern European immigrants to the United States, particularly Scandinavia, the general view that emerges from the comparison with Australia, Canada and the United States is of a relatively illiterate migratory flow to Latin America. This picture is broadly the case but needs to be qualified.

Southern and Eastern European immigrants to the United States showed the same low rates of literacy than those who migrated to Latin America (or even lower like the Southern Italians case). Argentinean statistics show that 40 percent of immigrants arriving in the peak years, 1880-1886 were illiterate. In 1914, a year of massive arrivals, the percentage had slightly increased to 42 whereas after the Great War it was much lower (18 percent). In the United States, 38 per cent of Southern and Eastern European immigrants arriving between 1899 and 1910 were illiterate, a percentage not very different than in Argentina'. Since Argentina received masses of immigrants it might be 
assumed that their literacy level was lower than more selective flows. However, the most diversified and urban economy of Argentina might a priori have attracted more literate immigrants than other Latin American countries. The latter seems not to be the case. Only 34 percent of immigrants older than 7 who arrived to the port of Santos in Brazil between 1908 and 1936 were illiterate. In the 1920s the percentage of illiterates for the native born population of Sao Paulo State were 73 per cent (Klein 1996)

Literate Spanish immigrants were to be found in Cuba before 1898 because of the colonial status of the island. But Cuba continued to attract literate Spaniards even after Independence. Thus the proportion of literate Spanish immigrants arriving on the island ranged from 63 percent in 1912 to 94 in 1924 (Losada 1999). Even with a high demand for unskilled labour on the sugar plantations the percentage of literates among Spanish immigrants increased ${ }^{\mathbf{1 0}}$.

According to Argentinean population census only 26 percent of Spaniards over the age of seven living in Argentina were illiterate in 1914 compared to 50 percent of the total Spanish population in 1910. Illiteracy rates in Italy were 38 percent in 1911, a percentage similar to that of the Italians living in Argentina. In Portugal nearly 70 percent of population was illiterate in 1910 compared with only 52 percent of Portuguese immigrants to Sao Paulo.

Table 3 presents a different picture of literacy rates for Italian and Spanish immigrants in Argentina before 1895. Data refers to a random sample from the original census of immigrants residents in Argentina in the census year. Significant differences are observed between rural and urban immigrants and in both cases between men and women. The overall picture is, for the two nationalities, one of extraordinary high literacy rates, particularly for Spanish male immigrants; these rates are certainly much higher than the populations of origin and also higher than those reported for Southern Europeans immigrants to the United States by O'Rourke and Williamson (1997). 
Table 3

Argentina 1895. Literacy Rates (\%)

Population older than 7 years old

A) Italians

\begin{tabular}{|c|l|l|l|l|l|}
\hline & Urban & & & \multicolumn{1}{|c|}{ Rural } & \\
\hline Males & & Females & & Males & Females \\
\hline 77.95 & & 66.51 & & 66.96 & 56.44 \\
\hline Total 100 & & Total 100 & & Total 100 & Total 100 \\
\hline $\mathrm{n}=3202$ & & $\mathrm{n}=2010$ & & $\mathrm{n}=775$ & $\mathrm{n}=388$ \\
\hline
\end{tabular}

B) Spaniards

\begin{tabular}{|c|l|l|l|l|l|}
\hline & Urban & & & \multicolumn{1}{|c|}{ Rural } & \\
\hline Males & & Females & & Males & Females \\
\hline 87.85 & & 68.65 & & 76.96 & 56.44 \\
\hline Total 100 & & Total 100 & & Total 100 & Total 100 \\
\hline $\mathrm{n}=2380$ & & $\mathrm{n}=1340$ & & $\mathrm{n}=465$ & $\mathrm{n}=235$ \\
\hline
\end{tabular}

Sources: Archivo General de la Nación. Population Census 1895. Archival files num. 466 to 584 and 800 to 1041 .

The issue is whether the proportion of immigrants possessing some levels of literacy was higher than those who remained at home, that is, if migrants were positively selected. Given the selectivity of migrants by age distribution and given the concentration of Southern Europeans emigrants from few regions, the comparison of immigrants' literacy rates with overall rates of residents is inadequate. In the three main European countries of origin, the northern regions from where the majority of immigrants were drawn tended to be more literate than other parts of the country, particularly in the Italian case. But in Italy the selectivity of the transatlantic migratory flow seems to have been lower than in other countries: the larger the migratory flow the closer the typical emigrant would be to the average population of origin. When immigrant's literacy is compared to literacy rates of potential emigrants from regions of high emigration the selectivity of the process appears quite clear for Spain and Portugal (Sánchez Alonso 1995; Costa Leite 1993). The evidence suggests that Southern Europe lost human capital to Latin America.

Another relevant issue is whether immigrants contributed to raise literacy levels in Latin America. The literacy levels of immigrants can be compared to those of native populations in Latin American receiving countries. Not all governments made the same effort to raise levels of education, but the data show that those countries with the smallest native populations around 1850 and the largest inflows of European immigrants displayed the lowest illiteracy rates around 1910 (Flora 1973). Latin 
American rankings are led by Uruguay (25 percent of illiterates in 1908). Uruguay was the country with the highest rate of immigration compared to native population. Argentina had 38 percent of illiterates whereas Chile, with much lower immigration rates than the River Plate region, had a 50 percent of illiteracy rate in the 1910s. Mexico's illiteracy rate was 72 percent of the population, higher than Brazil and Cuba with high proportions of population of African origin. These rates are certainly low compared to literacy rates for the same period for the United States, Canada and Australia. Immigrants raised literacy levels in some Latin American countries but other forces mattered more, particularly political commitment and taxes allocated to improve educational levels among their populations.

Did immigration add special skills or entrepreneurial capacities to the local labour force? Immigrants seem to have been over-represented among proprietors of industrial and commercial firms. They also contributed importantly to the formation of industrial and urban workforces. Immigrants in Argentina and Brazil accounted for disproportionately large shares of the workers in Sao Paulo and Buenos Aires manufacturing industries. Argentinean historians find immigrants played a positive role. Germani (1955) was among many historians to stress the modernizing role of immigrants and their exceptional contribution to the development of an entrepreneurial class in Argentina. But, according to Landes (1998: p. 321) Argentina selected underemployed peasants of little skills and education whose potential contribution to the economy was limited. For Brazil, Dean (1969) has argued that in the Southeast immigrants and their children played an important role as entrepreneurs in the industrialization in Sao Paulo and for the modernization of the rural sector. Leff (1997) disagrees and argues that immigration was neither a necessary nor a sufficient condition to promote development. Leff believes that if overseas immigrants had not been available, that supply of labour to fill the growing demand of industrial workers in Sao Paulo could have come from domestic sources. This is, however, a very difficult counterfactual to test. On the whole European workers retained a good reputation as workers both in the agricultural and the industrial labour forces. All reports from Brazil, Argentina, and Cuba concerning the productivity of Italians, Spaniards and Portuguese immigrants stress the fact that they were hard-working, sober and well-behaved. In contrast, the United States Immigration Commission concluded in 1911 that the "new" immigrants were "far less intelligent" than the "old" immigrants. (Quoted in Hatton and Williamson 1998, chap.7). 
No general conclusion can be drawn about the role of immigrants in supplying entrepreneurial and other skills or about contributions to the growth of internal demand. Positive representations are there in histories of Argentina and Uruguay. Immigrants did supply businessmen for Mexico and Chile but either for Cuba or for Brazil can immigration be credited for such an impact. Immigrants to Latin America from Southern Europe were positively selected by literacy and they carried higher literacy rates than native populations. On the whole, Latin America benefited clearly from European immigration. This does not imply that European immigrants were the key variable explaining economic growth before the 1930s. Those countries with the highest immigration rate displayed fast economic growth but policy, institutional stability, foreign capital and trade also played a crucial role.

\section{Section III. Was immigration a demographic gift or a demographic}

\section{burden?}

Immigrants who settled permanently in Latin America contributed to the growth of the population over the long run. This was especially true for countries like Argentina, Uruguay and Brazil. In the 1880s almost 26 percent of total population growth in Argentina was due to immigration. Over the next period, 1891-1910 the share fell to14 percent and down to 9 percent in the 1920s. In 1901-1920 immigration was responsible for only 7 percent of Brazilian population growth but in the years of high immigration, 1891-1900, the share was a spectacular 30 percent.

Immigration affects the overall rate of population growth by increasing absolute numbers and numbers of young people having children. It also has a direct impact on the age structure of the population. Migration is a highly selective process by age. In the short run, immigrants increase participation rates and contribute to the growth of the labour force, but in the long run the age structure of the population changes as the population grows. In recent years the debate on the influence of demography on economic growth has shifted the emphasis from population size and growth to age structures (Bloom, Canning and Sevilla 2002). People's economic behaviour varies at different stages of their life cycles. Thus, changes in a country's age structure can have significant effects on economic performance. Economic growth and population growth are related by modifications to the age structures of populations passing through demographic transitions. Dividing the population in three age groups, two dependants 
(the young and the old) and one economically active, each age group in a population exhibits different patterns of demand and savings. Children require intensive investment in health and education, prime-age adults supply labour and savings, and the elderly require expenditures upon health and retirement benefits (Coale and Hoover 1958, Kelley 1988).

Did immigration into Latin America increase the working age group and thereby produce a "demographic gift" for economic growth? Although policies to take advantage of this "gift" have to be implemented, immigrants are "ready-to-use" working population and lower the volume of resources devoted to the care of children. But immigrants as young adults also increase the number of dependents since they have and raise children in the host country hence creating a "demographic burden". Thus, it is important to measure the overall demographic effect of immigration in Latin America.

Immigrants contributed to the labour force growth and in the absence of immigration labour costs would have been higher. O'Rourke and Williamson (1999) have estimated that in 1910 real wages would have been 46 percent higher in Argentina without immigration. The Brazilian case is not so advantageous. Real wages would apparently have been only 2 percent higher in 1910 in the absence of mass migration. A larger labour force only becomes a gain when extra workers find jobs. Since immigrants left for Latin America because of the availability of jobs (and higher wages) we can assume that, in the short run, the majority of immigrants of working age recorded in population censuses in the receiving countries contributed to economic growth. Since population as a whole grows more slowly than active population, output per capita increased faster than output per worker.

Young permanent immigrants might also have raised birth rates and increased dependency burdens. Did countries of immigration have higher birth rates because of the arrival of young population? Or did immigrants contribute to an early start of the demographic transition by lowering birth rates? Already in 1895 the average number of children in Argentina was 8.4 for natives born and 6.1 for foreign born women, but most of differences can be explained by location (urban or rural) and literacy levels. By 1947 figures were 3.6 children per native woman compared to 3.2 for foreign females (Rechini de Lattes and Lattes 1975). Immigrants tend generally to converge to the demographic patterns of the host society; in the Argentinean case both native and foreign women seem to have converged to lower birth rates simultaneously. Populations that experienced rapid rate of increase in per capita income generally have lower 
mortality and lower fertility than those where per capita income grew more slowly. (1986) argued that the high birth rates of Latin America can be related to the large shares of populations that remained rural and that only developed and open societies had entered the first phase of the demographic transition by the first quarter of the twentieth century. Demographic transition seems then more related to structural changes than to the arrival of European immigrants.

In balance, immigrants contributed significantly to the growth of work forces. It seems clear that Argentina, Uruguay and several in the New World, derived economic advantage from immigration simply because the economically active population grew faster than the dependant populations in the years between 1870 and 1913 . However, this positive contribution may have been offset by accelerated population growth over the long run. For example, according to Taylor $(1992 ; 1994)$ high rates of immigration and more fecund immigrants to Argentina compared to Australia increased the dependent population group, depressed savings, inhibited capital deepening and retarded economic growth. During the Belle Époque capital imports maintained the level of output per worker but in the interwar years when foreign investment declined Argentina suffered from low domestic savings capacity, a function of high dependency burdens due to previous waves of pre-war immigration. The ratios of dependent population (0-15 age group plus those older than 64) to active population, were already higher in 1914 than dependency rates in Canada, Australia and the United States. In the 1940s those rates were however similar to those found in Canada but still higher than Australian and the United States.

Table 4 presents dependency rates in Latin America both for massive immigration countries and low immigration countries like Chile. In the late nineteenth century, Cuba had the lowest dependency rates. Argentina and Chile, with very different experiences with immigration had similar dependency rates, while Mexico and Uruguay had the highest. In the first decade of the twentieth century, Argentina had the lowest dependency rate attributable to the rapid increase of working age population due to immigration. Brazilian immigration policy which favoured family arrivals could have contributed to the rise in the dependency rate. But in Cuba, where immigration from Europe was predominately male immigration with no children, native population growth and perhaps the influx of Caribbean immigrants increased the dependency rate notably. The Argentine tendency of decreasing the dependency rate is clear in 1947. Even in the 1940s when the demographic transition was on its way in more Latin 
American countries that in the preceding period, Argentina clearly had the lowest dependency rates of all.

Table 4

Dependency Rates: Latin America and other New World Countries (1872-1947)

\begin{tabular}{|c|c|c|c|c|c|c|c|}
\hline $\begin{array}{l}\text { Countries } \\
\text { Argentina }\end{array}$ & $\begin{array}{l}1869 \\
\mathbf{0 . 8 3 9}\end{array}$ & $\begin{array}{l}1895 \\
\mathbf{0 . 7 3 4}\end{array}$ & & $\begin{array}{c}1914 \\
\mathbf{0 . 6 8 8}\end{array}$ & & & $\begin{array}{l}1947 \\
\mathbf{0 . 5 3 3}\end{array}$ \\
\hline Brazil & $\begin{array}{c}1872 \\
\mathbf{0 . 7 1 9}\end{array}$ & $\begin{array}{l}1890 \\
\mathbf{0 . 7 5 5}\end{array}$ & $\begin{array}{r}1900 \\
0.907\end{array}$ & & $\begin{array}{l}1920 \\
\mathbf{0 . 8 8 0}\end{array}$ & & $\begin{array}{l}1940 \\
\mathbf{0 . 8 1 5}\end{array}$ \\
\hline Cuba & & $\begin{array}{c}1889 \\
0.643 *\end{array}$ & $\begin{array}{c}1907 \\
\text { 0.698* }\end{array}$ & & $\begin{array}{c}1919 \\
\text { 0.891* }\end{array}$ & & $\begin{array}{l}1943 \\
\mathbf{0 . 6 6 0}\end{array}$ \\
\hline Uruguay & & $\begin{array}{c}1900 \\
\mathbf{0 . 8 5 4}\end{array}$ & $\begin{array}{r}1908 \\
\mathbf{0 . 7 7 7}\end{array}$ & & & & \\
\hline Mexico & & $\begin{array}{c}1895 \\
\text { 0.813* }\end{array}$ & $\begin{array}{c}1900 \\
\text { 0.805* }\end{array}$ & $\begin{array}{l}1910 \\
\mathbf{0 . 8 0 1}\end{array}$ & & $\begin{array}{c}1930 \\
\mathbf{0 . 8 0 2} *\end{array}$ & $\begin{array}{l}1940 \\
\mathbf{0 . 7 9 6}\end{array}$ \\
\hline Chile & & $\begin{array}{l}1895 \\
\mathbf{0 . 7 7 2}\end{array}$ & $\begin{array}{c}1907 \\
\text { 0.784* }\end{array}$ & & $\begin{array}{l}1920 \\
0.702\end{array}$ & $\begin{array}{r}1930 \\
\mathbf{0 . 6 8 5}\end{array}$ & \\
\hline Canada & $\begin{array}{l}1871 \\
\mathbf{0 . 8 8 3}\end{array}$ & $\begin{array}{l}1891 \\
0.692\end{array}$ & & $\begin{array}{l}1911 \\
\mathbf{0 . 6 0 0}\end{array}$ & $\begin{array}{l}1921 \\
0.645\end{array}$ & $\begin{array}{r}1931 \\
\mathbf{0 . 5 9 8}\end{array}$ & $\begin{array}{l}1941 \\
\mathbf{0 . 5 2 6}\end{array}$ \\
\hline Australia & $\begin{array}{l}1861 \\
0.610\end{array}$ & $\begin{array}{l}1891 \\
0.666\end{array}$ & $\begin{array}{r}1901 \\
0.643\end{array}$ & $\begin{array}{l}1911 \\
\mathbf{0 . 5 2 0}\end{array}$ & $\begin{array}{l}1921 \\
0.567\end{array}$ & $\begin{array}{r}1933 \\
\mathbf{0 . 5 0 0}\end{array}$ & $\begin{array}{l}1947 \\
\mathbf{0 . 4 9 6}\end{array}$ \\
\hline US & $\begin{array}{l}1870 \\
\mathbf{0 . 7 5 4}\end{array}$ & $\begin{array}{l}1880 \\
\mathbf{0 . 6 8 6}\end{array}$ & $\begin{array}{r}1900 \\
\mathbf{0 . 6 3 2}\end{array}$ & $\begin{array}{l}1910 \\
\mathbf{0 . 5 4 7}\end{array}$ & $\begin{array}{l}1920 \\
0.573\end{array}$ & $\begin{array}{r}1930 \\
\mathbf{0 . 5 3 3}\end{array}$ & $\begin{array}{l}1940 \\
0.488\end{array}$ \\
\hline
\end{tabular}

*Age group (15-60)

The dependency rate is the ratio of dependent population (ages $0-15)+($ over 64$)$ to potentially active population (ages 15-64)

Sources: Calculated from Mitchell (1993) and (1983)

The idea of the demographic burden in Argentina depends entirely on the basis of the comparison. Within Latin America Argentina and Uruguay, the highest recipients of Southern European immigrants, had the lowest dependency rates since the beginning of the twentieth century. Several forces (other than immigration) appeared to raise burdens of dependency in Latin America.

\section{A new research agenda: the role of social capital}

A new research agenda should include new problems and hypotheses.

Immigrants not only affected population and workforce growth; they also contributed to the creation of social capital correlated by economists with good economic performance (Dasgupta and Serageldin 1999). There is an abundant literature on the associations and 
societies created by immigrants in the host countries. The concept of social capital, based on trust, cooperation and shared civic values can be very usefully applied to the role immigrants played in associational activities in several Latin American countries. Cultural affinity also makes a contribution to the creation of social capital. Southern Europeans in Latin America had a cultural capital with includes language, manners, religion and values which were readily accepted in the host countries. Immigrants certainly contributed to the creation and operation of associations and cooperative organizations in several Latin American countries. They formed mutual aid societies, published newspapers, joined clubs and churches and founded various associations. Particularly the Italians have received a preferential attention (Baily 1999, Devoto and Fernandez 1988 and Devoto 1984, among others). High levels of social capital have been found in Northern Italy compared to the south. Since social capital is assumed to be transferable it might be that Latin American countries received not only more literate and skilled Italian immigrants than the United States but also immigrants with the ability to create social capital. Argentina received the largest inflow of Northern Italians thus importing social capital from Europe. Italians in Latin America might have succeeded precisely because they had higher levels of social capital than the native population or other immigrants groups.

The value and uses of social capital depend on the institutional environment and it might be the case that Argentina had an exceptional institutional environment for the development of immigrants' social capital abilities compared to other Latin American countries. Both Baily (1999) and Moya (1998) ponder the importance of the social and institutional networks that facilitated the insertion of Italians and Spaniards into Argentine society. High levels of social capital have also been associated with high levels of human capital. It could be the case that public commitment to education in different countries was also influenced by the stock of social capital. Electoral participation also provides a key measure of social capital for a given country. Immigrants' associations have always been studied from the point of view of the immigrant communities. The majority of the research done has concentrated on the internal life of the association, ruling members and their connections with local authorities and, above all, the efforts made to preserve the roots with the communities of origin. Nothing has been said about whether some associations were created by natives in the host country as a reaction to the immigrant flow. Since social capital describes circumstances in which individuals can use membership in groups and 
networks to secure benefits (economic or not) historians who had worked on immigrants networks and associations can contrast some of the existing theories about cooperative arrangements and social capital. For example, it is well known that mutual aid societies were attractive for the insurance benefits that they offered to their members and, by extension, to their families. These organizations often offered selective benefits to members like life insurances, hospital assistance, free medical care or widowers and orphans support. Opportunities for trust and fellowship were, however, important byproducts of the need for economic security. This important avenue of research regarding mutual aid societies is still waiting for Latin American countries (For the US see Gamm and Putnam 2001). Social capital analysis can definitely contribute to the revival of immigrants' associational life studies from the dead end it seems to be in the last years and can shed new light on the contribution of immigration to economic development in the long run from a new perspective.

This paper surveys Latin America immigration experience since the late nineteenth century to 1930. It assesses inferences about European migrants in Latin America derived from the experience of migrants in the United States and questions its validity.

The global economy evolved slowly through the nineteenth century. Voluntary migration flows reached their highest levels in the early decades of the twentieth century. Latin American countries like Argentina, Uruguay, Cuba and Brazil participated actively in the international labour market. Several other countries in the region, remained, however, outside this market.

The experiences of Latin American countries are not fully incorporated into current debates on the cost and benefits from Atlantic migration despite the fact that 13 million of Europeans migrated to that region between 1870 and 1930. Latin America was a late comer to the age of mass migration. Migratory flows only became really large and significant in the early years of the twentieth century prior to World War One and the international labour market changed dramatically after the War. When mass European immigration to Latin America started in the 1880s, it was clear that the region could not compete with the United States.

European immigration to Latin America from the 1880s onwards presents us with similar patterns to those of other parts of the Americas and Australia. The same economic and demographic forces operated between sending and receiving regions in the Latin American segment of the international labour market. Immigrants to Latin 
America also came from latecomer countries to emigration from Europe and were in several respects different from those who crossed the Atlantic in early phases of the movement. On balance, Latin America received poorer and potentially less productive immigrants than the United States simply because the dominant stream emigrating from Europe over the years 1880-1914 came from the economically backward areas of Southern and Eastern Europe. But these migrants arrived also to the United States. Yet their adjustment to the host labour markets in Latin America seems to have been quite successful particularly in urban sectors but future analysis will wish to distinguish between first and second generation of immigrants. Furthermore qualifications can be made about the prevailing representation of immigrants in Latin America as unskilled, illiterate and low productive labour. Immigrants made rational choices of where to go. They went to places where their handicaps (in language, education and literacy) would be minimized because demands for unskilled labour were high. Lacking of specific skills may have been an advantage in the adaptation process to new urban labour markets. Rates of literacy were certainly lower among Latin American immigrants than Northern European emigrants going to the United States, Canada and Australia, but very similar to the overall flow of Southern and Eastern Europeans. In Latin America migrants were positively selected from their countries of origin, particularly in the Iberian Peninsula, according to literacy. Further more, immigrants had higher literacy rates than the native populations of Latin America and countries with the smallest native population around 1870 and the largest inflow of European immigrants, showed the highest literacy rates around 1910.

Immigration had an impact on labour force and population growth. Migrants raised the dependent age groups in the population, particularly children, in the medium and long run. Since the debate on the influence of demography on economic growth has shifted the emphasis from population size and growth to the economic consequences of the age structure of the population, the long run impact of large numbers of young immigrants to Latin American countries, other than Argentina, waits for a promising research.

Migration history is clearly biased in favour of the United States. It is dominated by a narrow conception of the "Atlantic Economy" and when dealing with Latin America is still full of over-simplifications. This paper has aimed to qualify some of the traditional representations. To consider migrants other than the Europeans should be the next step in the global history of migration in Latin America. 


\section{References}

Adelman, J. (1994) Frontier Development. Land, Labour and Capital on the Wheatlands of Argentina and Canada, 1890-1914. Oxford: Clarendon Press

Appleby, J. (1992 "Recovering America's Historic Diversity: Beyond Exceptionalism”. The Journal of American History, 79, 2, pp. 419-431

Bethell, L. (ed.) (1986) The Cambridge History of Latin America, Cambridge: Cambridge University Press

Baily, S. L. (1999) Immigrants in the Land of Promise: Italians in Buenos Aires and in New York City, 1870 to 1914, Ithaca, New York: Cornell University Press

Bloom, D. E., Canning, D. and Sevilla, J. (2002) The Demographic Dividend: a New perspective on the Economic Consequences of the Population Change, Santa Monica, Calif.: Rand Publications

Bulmer-Thomas, V. (1994) The Economic History of Latin America Since Independence, Cambridge: Cambridge University Press

Cinel, D. (1991) The National Integration of Italian Return Migration, 1870-1929, Cambridge: Cambridge University Press

Cipolla, C. (1969) Literacy and Development in the West, Baltimore: Penguin Books

Coale, A. J. and Hoover, E. M. (1958) Population Growth and Economic Development in Low-Income Countries, Princeton: Princeton University Press

Conrad, R. (1975) "The Planter Class and the Debate over Chinese Immigration to Brazil, 1850-1893”, International Migration Review, 19, 1, pp. 41-45

Cortés Conde, R. (1979) El progreso argentino, 1880-1914, Buenos Aires: Ed. Sudamericana.

Costa Leite, J. (1993) "Portugal and Emigration, 1855-1914", Ph.D. Dissertation, Columbia University

Dasgupta, P. and Serageldin, I. (eds.) (1999) Social Capital. A Multifaceted Perspective, Washington DC: The World Bank

Dean, W. (1969) The Industrialization of Sao Paulo, 1880-1945, Austin: University of Texas Press

Devoto, F. (1984) "Las sociedades italianas de ayuda mutua en Buenos Aires y Santa Fe. Ideas y problemas", Studi Emigrazione, 21, 75, pp. 132-151

Devoto, F. and Fernandez, A. (1988) "Asociacionismo, liderazgo y participación en dos grupos étnicos en áreas urbanas de la Argentina finisecular", in Fernando Devoto and Gianfausto Rosoli (eds.), L'Italia nella societá argentina, Roma: Centro Studi Emigrazione, pp. 109-208 
Diaz Alejandro, C. (1970) Essays on the Economic History of the Argentine Republic, New Haven: Yale University Press

Eltis, D. (1983) "Free and Coerced Transatlantic Migrations: Some Comparisons", American Historical Review, 88, 2, pp. 251-280

Engerman, S. L. and Sofoloff, K. L. (2005) "Colonialism, Inequality and Long-Run Paths of Development”, NBER Working Paper 11057

Faini, R. and Venturini, A. (1994) "Italian Emigration in the Pre War Period" in Timothy J. Hatton and Jeffrey G. Williamson (ed.) Migration and the International Labor Market, 1850-1939, London: Routledge, pp. 72-90

Ferenczi, I. and Willcox, W. F. (1929, 1931) International Migrations, Vols. 1 and 2, New York: National Bureau of Economic Research

Flora, P. (1973) "Historical Processes of Social Mobilization: Urbanization and Literacy", in S.N. Eisenstadt and S. Rokkan (eds.), Building States and Nations: Analyses by Region, London: Sage, pp. 213-256

Gallo, E. (1983) La Pampa gringa. La colonización agrícola en Santa Fe, 1870-1879, Buenos Aires: Ed. Sudamericana

Gamm, G. and Putnam, R. D. (2001) "The Growth of Voluntary Associations in America, 1840-1940”, in Robert I. Rotberg (ed.), Patterns of Social Capital. Stability and Change in Historical Perspective, Cambridge: Cambridge University Press

Germani, G. (1955) Estructura social de la Argentina, Buenos Aires: Ed. Raigal

Gould, J. D. (1979) "European Inter-Continental Emigration, 1815-1914: Patterns and Causes", Journal of European Economic History, 8, 3, pp. 593-679

------ (1980) "European Inter-Continental Emigration. The Road Home: Return Migration from the U.S.A.”, Journal of European Economic History, 9, 1, pp. 41113

Hatton T. J. and Williamson, J. G. (2005) Global Migration and the World Economy. Two centuries of Policy and Performance, Cambridge, Mass., MIT Press

(1994) "Latecomers to Mass Migration: The Latin Experience" in T.J. Hatton and J.G. Willaimson (eds.) Migration and the International Labor Market, 18501939, New York: Routledge, pp. 5-71

- (1998) The Age of Mass Migration. Causes and Economic Impact, New York: Oxford University Press

Holloway, T. H. (1980) Immigrants on the Land. Coffee and Society in São Paulo, 1886-1934, Chapel Hill: University of North Carolina Press 
Kelley, A. C. (1988) "Economic Consequences of Population Change in the Third World", Journal of Economic Literature, 26, pp. 1685-1728

Klein, H. S. (1983) "The Integration of Italian Immigrants in to the United States and Argentina: A Comparative Analysis", American Historical Review, 88, 2, pp. 306329

(1996) La inmigración española en Brasil, Gijón: Fundación Archivo de Indianos

(1999) The Atlantic Slave Trade, Cambridge: Cambridge University Press

Leff, N. H. (1982) Underdevelopment and Development in Brazil. Economic Structure and Change, 1822-1947, Vol. I, London: Allen \& Unwin

(1997) "Economic Development in Brazil, 1822-1913" in S. Haber (ed.), How Latin America Fell Behind. Essays on the Economic Histories of Brazil and Mexico, 1800-1914, Stanford: Stanford University Press, 1997, pp. 34-64

Lewis, W.A. (1978) Growth and Fluctuations, 1870-1913, London: George Allen \& Unwin

Lida, C. E. (comp.) (1994) Una inmigración privilegiada. Comerciantes, empresarios y profesionales en México en los siglos XIX y XX, Madrid: Alianza

Losada, A. F. (1999) Cuba: población y economía entre la independencia y la revolución, Vigo: Universidad de Vigo

Maddison, A. (2001) The World Economy. A Millenial Perspective, Paris: OECD

Maluquer de Motes, J. (1992) Nación e Immigración: los españoles en Cuba (ss. XIXy $X X)$, Gijón: Ed. Jucar

Merrick, T. W. and Graham, D. H. (1979) Population and Economic Development in Brazil, 1800 to the Present, Baltimore: The John Hopkins University Press

Miguez, E. J. (1993) "La movilidad social de nativos e inmigrantes en la frontera bonaersense en el siglo XIX", Estudios Migratorios Latinoamericanos, 24, pp. 139169

Mitchell, B. R. (1993) International Historical Statistics. The Americas 1750-1988, Basingtoke, England: Macmillan

Moya, J. C. (1998) Cousins and Strangers. Spanish Immigrants in Buenos Aires, 18501930, Berkeley: University of California Press

O'Rourke, K. and Williamson, J. G. (1997) “Around the European Periphery, 18701913: Globalization, Schooling and Growth", European Review of Economic History, 1, pp. 153-191 
(1999) Globalization and History. The Evolution of a Nineteenth-Century Atlantic Economy, Cambridge, Mass.: MIT Press

Rechini de Lattes Z. and Lattes, A. E. (1975) La población argentina, Buenos Aires: Instituto Nacional de Estadística y Censos

Sacerdote, B. I. (1995) “On Transport Cost From Europe to the New World”, Unpublished manuscript, Harvard University

Sánchez-Albornoz, N. (1986) "The Population of Latin America, 1850-1930" in Leslie Bethell (ed.) The Cambridge History of Latin America, vol. 4, Cambridge: Cambridge University Press, pp. 121-151

Sánchez-Alonso, B. (2000a) "European Emigration in the Late Nineteenth century: The Paradoxical Case of Spain”, Economic History Review, 52, 2, pp. 309-329

(2000b) "Those Who Left and Those Who Stayed Behind: Explaining Emigration from the Regions of Spain, 1880-1914”, Journal of Economic History 60 (3), pp. 730-755.

(1992) La inmigración española en Argentina. Siglos XIX y XX, Gijón: Ed. Júcar

Solberg, C. E. (1987) The Prairies and the Pampas: Agrarian Policies in Canada and Argentina, 1880-1930, Stanford: Stanford University Press

Taylor, A. M. (1997) "Latifundia as a Malefactor in Economic Development? Scale, Tenancy and Agriculture in the Pampas, 1880-1994", Research in Economic History, 17 , pp. $261-300$

----- (1994) "Mass Migration to Distant Southern Shores. Argentina and Australia, 1870-1939" in Timothy J. Hatton and Jeffrey G. Williamson (eds.) Migration and the International Labor Market, 1850-1939, London: Routlegde, pp. 91-115

------ (1992) "External Dependence, Demographic Burdens and Argentine Economic Development After the Belle Epoque", Journal of Economic History, 52, pp. $907-$ 936

Thistlethwaite, F. (1960) "Migration from Europe Overseas in the Nineteenth and Twentieth Centuries", reprinted in R. J. Vecoli and S. M. Sinke (1991), A Century of European Migrations, 1830-1930, Chicago: University of Illinois Press, pp.17-57

Vázquez Gonzalez, A. (1999) “La emigración gallega a América, 1830-1930”, Ph D dissertation, Universidad de Santiago de Compostela

Williamson, J. G. (1999) "Real Wages Inequality and Globalization in Latin America before 1940", in Pablo Martín Aceña, Adolfo Meisel and Carlos Newland (eds.), La historia económica en América Latina, Revista de Historia Económica, Special issue, pp. 101-142 
Figure 1

Real Wages Relative to the Mediterranean Countries (1913=100)

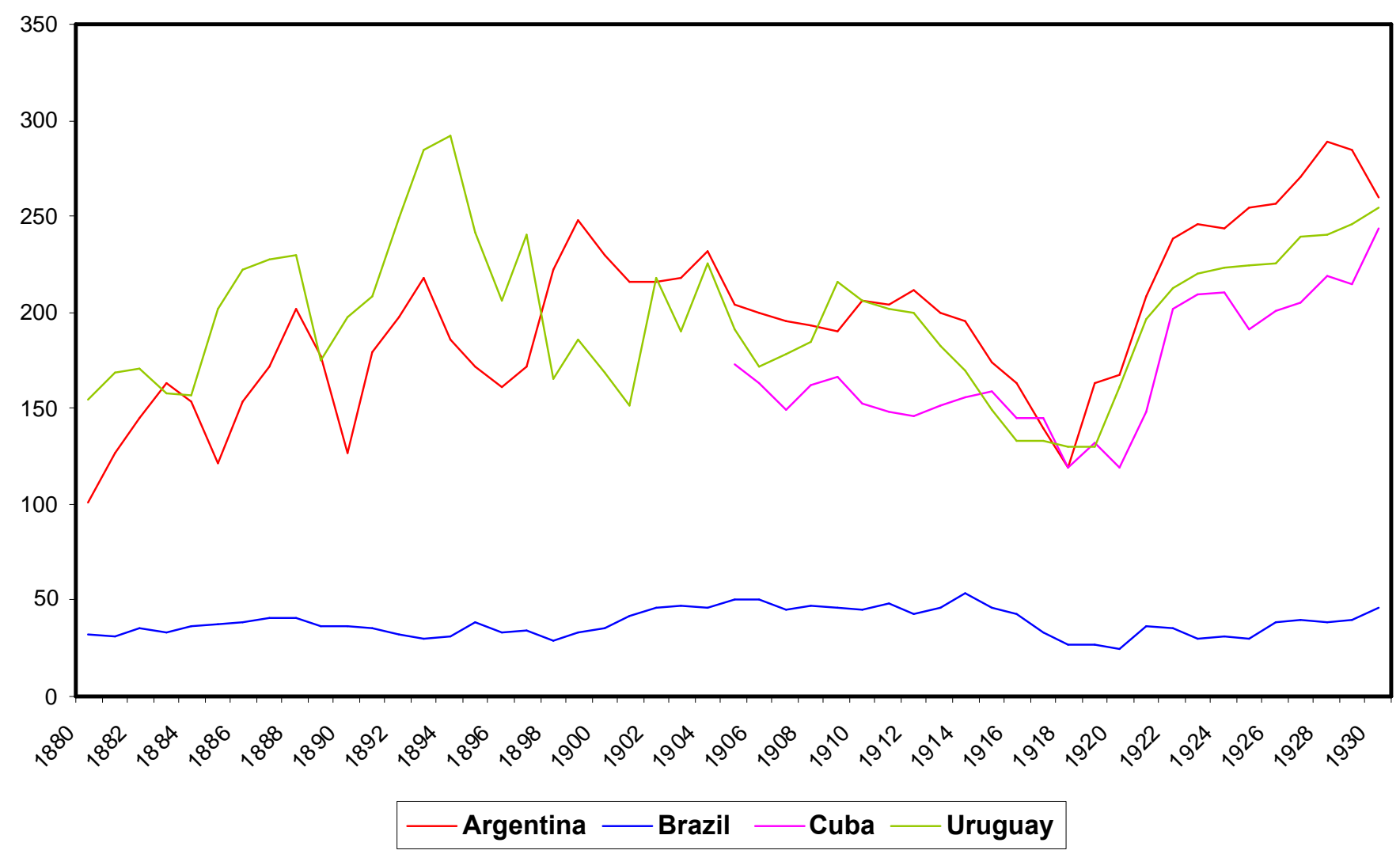

Sources: Williamson (1999) 
${ }^{1}$ The distinction between free and coerced labour is important here since Latin America was one of the major participants in the Atlantic slave trade. Klein (1999), Eltis (1983)

${ }^{2}$ I am grateful to Tim Dore for this reference and to Bruce Sacerdote for allowing me to use his unpublished data.

${ }^{3}$ It should be bear in mind that Spanish data refers to prices from Galician ports. The trip from the Canary Islands to Cuba was cheaper.

${ }^{4}$ See the special issue of the Jahrbuch für Geschichte von Staat, Wirtschaft und Geselleschaft Lateinamerikas, 13 (1976)

${ }^{5}$ Going back to the Dillingham Commission in the USA, the general belief of the low quality of immigrants from Southern Europe has been repeated in almost all general accounts of transatlantic migration.

${ }^{6}$ That is why research with nominative data, as Moya (1998) for the city of Buenos Aires, proved so useful.

${ }^{7}$ Urbanizations rates were 27, 12 and 17 percent in Italy, Portugal and Spain respectively

${ }^{8}$ For example, the high proportion of Spanish-born bank clerks in Cuba in 1907 (57 percent) reflects the weight of the Spanish banks in the island years before the Independence (Maluquer de Motes 1992).

${ }^{9}$ Data refers to immigrants over 14 years of age. US Immigration Commission, vol. III, table 15, 1907 1910

${ }^{10}$ Data might also reflect the general upward trend in Spanish literacy in the 1920s. 